\title{
Linguo-pragmatic Aspect of "Search for the Ideal" in the Discourse of Female Fiction as a Reflection of Matrimonial-Demographic and Sexual Behavior in Contemporary Russian Society
}

\author{
Irina Sovetovna Karabulatova ${ }^{1}$, Zaineta Ruslanovna Khachmafova ${ }^{2}$, Madina Marzakanovna Bricheva ${ }^{2}$, Tamara \\ Teuchezhevna Nescheretova ${ }^{2} \&$ Asya Kazbekovna Bersirova ${ }^{2}$ \\ ${ }^{1}$ Institute of Social and Political Research, Russian Academy of Sciences, Moscow, Russian Federation \\ ${ }^{2}$ Adyghe State University, Maikop, Russian Federation \\ Correspondence: Irina S.Karabulatova, Leninsky Prospect, 32a, Moscow, 119991, Russian Federation.
}

Received: February 28, 2015 Accepted: March 20, 2015 Online Published: April 24. 2015

doi:10.5539/res.v7n6p35

URL: http://dx.doi.org/10.5539/res.v7n6p35

\begin{abstract}
Female fiction discourse possesses particular specificity of world outlook and gender conditioned linguistic peculiarities, representing female linguistic personality. The ways to reflect the linguistic consciousness of the female linguistic personality in the literary text in terms of cognitive linguistics are studied in the article. One of the ways to represent the cognitive level of female linguistic personality in the literary text is considered in the concept "MAN", involving the object—image — bearing, notional and valuation — estimative constituents. The authors study the characteristics, belonging to the "ideal man", perceived by the contemporary Russian women, how these characteristics correlate with the evolution of gender relations in the society. The results of the article can be used to construct gender tendencies in modern Russian society; they can provide the material to forecast further matrimonial - demographic and sexual behavior of Russian women. The analysis of female literature, carried out in this investigation, is provided against the sociological research of gender and orientations on family, love, marriage in the women of Russian society.
\end{abstract}

Keywords: a gender, a female discourse, linguistic consciousness, a concept "man", matrimonial behavior, sexual behavior, reproductive behavior

\section{Introduction}

A wave of interest to philosophical analysis of language and text problems covered gender investigations-a young discipline, rather popular in Western and American, but still developing momentum in Russian humanitaristics (Zherebkina, 2000; Avery \& Liss, 1996; Lazar, 2007; Clarck, 2012). Under the last one, a special sphere, studying the problem of language and gender interconnection-gender linguistics, was formed; it is being developed in close cooperation with feminist criticism of language (Castro, 2013; Gvozdeva et al., 2005; Khachmafova, 2010; Queen, 1997; Posch, 2009). In 1980, the notion of text becomes "one of the conceptual notions of the feminist criticism of language even for those authors, for which the subject of language or literature does not present the main subject of investigation" (Zherebkina, 2000).

Female literature presents a complex cultural phenomenon, uniting the woman-author and the woman-reader, and representing the specificity of female linguistic worldview. "Female" literary text reproduces a peculiar cast of the epoch, demonstrates a model of personality of the new epoch, born in keeping with gender canons and everyday stereotypes. In female prose, we see the reflection of evolution of stereotypes in sexual, marriage and reproductive behavior of Russian woman. Thus, we observe the reflection of stable matrimonial stereotypes of the Russian society in female prose: 1) Only official marriage; 2) Impermissibility of divorce; 3) Impermissibility of infidelity (divorce and infidelity were considered as sins); 4) Obligatory marriage (early and total marriage, the share of final celibacy is nearly $5 \%$ ); 5) Widowhood is the visitation; 6) The desirability for remarriage (but not the third-fourth).

Earlier, the woman, being the treasurer of purity of generation and family, had the strictly regulated sexual behavior. In this connection, the sexual female behavior was characterized by the following allowable features: 1) Moral-religious sexuality; 2) Veneration of chastity, moderateness, blush and virginity; 3) Condemnation of unproductive sexual relationship. These traits of female behavior were dominating up to the breakup of the 
USSR. Reproductive female behavior was respected in all layers of Russian society. However, on the one hand, children present the undeniable value of family and society (what was conditioned by the economic reasons), but, on the other hand, children required considerable expenditures (especially in the prime of life). Alongside with that, regulation of birth rate and interruption of pregnancy were prohibited (Karabulatova, 2004). There are correlation points between the processes of female emancipation and development processes of the phenomenon of female prose. Women-writers open a new woman's world in their works, as viewed by women, and suggest the society not only new themes, but also new behavior samples, assert women's rights for independent choice, individual fate. A phenomenon of female emancipation resulted in the change of stereotypes of female behavior in the society; it was also reflected in the female prose. Thus, modern female matrimonial behavior admits the following: 1) Civil marriage (and other forms of marriage: guest marriage, marriage of convenience, hetaerism, fictitious, temporary, virtual marriage etc.); 2) Admissibility of divorce; 3) Admissibility of infidelity and free relations; 4) Admissibility of celibacy and orientation at the career; 5) Sympathetic relation to widowhood. Sexual behavior of women in Russian society was also changed: 1) Aggressive sexuality; 2) Admissibility of free sexual relationships. Regarding the reproductive behavior, the Russian woman today regulates the reproduction herself. Among the Russian women, both child-free and children of unwed parents are admissible (as a rule, one child for a woman in the end of the reproductive age). Such tendencies could not but be reflected in the female prose, showing the breakage of stereotypes both inside the Russian society in whole, and inside the woman in particular.

Let us underline, that the appearance of women-authors, writing fiction, where the woman, who makes the life herself, is in the center of narration, laid the foundation of the phenomenon of female prose. Undoubtedly, the appearance of the female prose phenomenon requires definite sociocultural situation: the situation of the society of mass culture, with all its attributes of production, reproduction and consumption of mass literature. Thus, initially, high value of mutual feelings was actually replaced by the real lack of marriage partners that is why the families, created for fear of loneliness, were not lasting. Female prose is the phenomenon of mass literature, which legitimates the marginalized female experience through the practices of self-identification. One has to agree with Y. M. Lotman, who mentioned, that "the woman conquered the right in biography" (Lotman, 1994). The struggle of new and old stereotypes resulted in escalation of the main female theme-expectation of prince. According to the famous writer V. Tokareva, the main theme of the woman's creative work is the grief for the ideal. "A man in his creative work is oriented at the God. The woman is oriented at the man. However, the object of love does not correspond to the ideal. Then, the woman suffers and writes about it. The main theme of woman's creative work is the grief for the ideal" (Tokareva, 1995).

Thus, when studying gender methodology of the text analysis, it shall be noted, that it was the first, where the themes of gender and language interconnection began to be problematized, as well as the specificity of man and woman communication, discourse, woman's authorship and writing at philosophical level (Khachmafova, 2009; Hart, 2010). At that, this methodology focused attention on exposure and elimination of several orientations of patriarchal culture: male (writing, language, discourse, text) is a standard, female is a deviation; male is positive, female is negative; man dominates in language, woman is hidden. At that, the alternative orientations were suggested: speaking (discourse, writing) on behalf of the woman both in the dialogue and in the culture; reconsideration of history in her female version (her-story); rearrangement of axiological accents, removal of "negative image", when evaluating the female text; the formation of specifically female view, special way for female reading and writing, the creation of female text, free from male domination.

Undoubtedly, human consciousness plays an important role in development and support of gender system. As a rule, modeling of gender identity starts in childhood, where the whole "traditional culture of childhood acts as a guidance mechanism of one or another form of social identity" (Karabulatova, 2004), and "the feminist movement has already influenced much on text representations of women, men, boys and girls" (Sunderland, 2011). Later, the individual gender consciousness is being constructed by means of distribution and support of social and cultural stereotypes, standards and regulations; if people break them, they are punished by the society (for instance, the labels "a virago" or "a man, who behaves like a woman" are experienced by people rather painfully, and they can cause not only stresses, but different types of mental disorders).

\section{Materials and Methods of Investigation}

The literary texts of women-prose-writers of the modern literature of the XX-XXI centuries in Russian language presented the empiric material, as well as theoretic data, accumulated in different spheres of modern linguistics: in text linguistics, linguo-poetics, cognitive linguistics, stylistics, literary text. We analyzed the works of V. Tokareva, L. Ulitskaya, O. Robsky, M. Krasheninnikova, N. Sukhanova, L. Petrushevskaya, which brightly illustrate modern women social and linguistic consciousness. From the works of V. Tokareva, we took the 
following: "Instead of me" (1995), "The Conservation Law" (2007), "As soon as the Mist has fallen..." (2007), "Horses with Wings" (2004), "To Say or not to Say" (1991), "Do not Create" (2011), "Anton, Put on the Shoes" (2001), "The Greek was Riding" (2007), "Apologize. They will not Shoot" (2007), "One Block of Hope" (2011), "A Long Day" (2000), "Zigzag" (2008), "The Dog was Walking along the Piano" (1995). The creative work of Ludmila Ulitskaya is presented by such works, as "The Queen of Spades" (2001), "Medea and her Children" (2012), "Zu-urich" (2005), "The Women of Russian Villages" (2008).

In her novel "Medea and her Children", L. Ulitskaya demonstrates the new female formation of myths. We see family behavior of single woman inside huge generation, her motivation for celibacy, her attitude towards children and the attitude of surrounding people (relatives or unfamiliar) towards the lead character Medea Mendes. Depicting the family interrelations, starting from the 10th century and finishing with 1995, L. Ulitskaya shows the evolution of woman's behavior in love and marriage. We see those metamorphoses, happening with the lead character, were inevitable. The author postulates, that the family is the main value. Special interpretation of family problematics, presented by L. Ulitskaya, conditioned high concentration of dialogues, where the interpersonal and intergenerational relations are revealed, as well as the monologues, reflecting the characters' inner world. Besides, the novel author principally pays attention to the fact, that at the pleasure of Fate, numerous relatives of Medea turned out to be scattered all over the world (Georgia, Israel, Lithuania, Siberia, Italy, Central Asia, Haiti, the USA), that is why "the other", "foreign" traits penetrate into the life itself and into the characters of relatives (other national influences, other traditions, customs etc.), but the family, married origin overrules: they all tend to bring their children to Crimea, to the motherland of their ancestors. Here L. Ulitskaya shows, how the "modeling of linguistic personality takes place in conditions of globalization and migration" (Karabulatova, 2013). The author uses the dualism of female and male in the story "Zu-urich". The main male part in this piece is the role of foreign prince, some hero-saver, which is connected with the implementation of secrete female dream, with the illusion of wonderful transformation of "the last" into "the first". Matrimonial ambitions of the lead character are underlined by the sphere of material-physical and everyday existence of the lead character Lidiya or Lidka the Goose. At the same time, the male world is mainly perceived in fairytale-mythological plane. The breakthrough from the vicious circle of the monotonous everyday life of Lidka the Goose - the foreign marriage of the heroine-becomes possible thanks to the unexpected-fairytale appearance of the man-hero in the everyday life. It is necessary to say, that the author managed to notice the main traits of matrimonial behavior of contemporary Russian women, able to marry any foreigner, even if he is a migrant worker (Ryazantsev et al., 2014). The investigator of glamorous life O. Robsky is presented by her novel "CASUAL/The Everyday" (2005). This ironical story-telling differs from the female narration of other writers by the specificity of narration, presentation and the heroes themselves. L. Petrushevskaya in her pieces "The Possibility of Mennipean. Three Voyages" (2000), "Where I was" (2002) is aligned with T. E. A. Gofman, whose worlds of reality and irreality were interpenetrated in such a way, that the readers were frequently enmeshed in his worlds.

Methodological novelty of the text analysis has become the fact, that, firstly, the sphere of investigation was expanded (the possibilities to study female texts, female writing and authorship appeared), and secondly, absolutely new methods and ways of investigation appeared (including the phenomena of female reading, the specificity of female perception). The development process of gender methodology of text analysis was closely connected with the similar processes in modern philosophical movements. On the one hand, feminist critics used structural and postmodern results in their methodology, on the other hand, the representatives of poststructural and postmodern philosophy (Derrida, Kristeva, Lakan and others) were in many ways based on the concepts of feminism and gender investigations. For instance, J. Derrida, denying the old text approach: "to use them "in order to get profit", appealed for working with texts under the dialogue principle, the search for something, that was not articulated in the text; he admitted "the existence of the variety of cultural interpretations" (Derrida, 2012). Female literature unites the literary texts, created by women mainly for women (Khachmafova, 2009; Okhotnikova, 2002; Pischler, 2009). At that, it is necessary to note, that “the author's and reader-investigator's gender, in other words, gender system of the society influences much on creation and interpretation of literary pieces" (Ryutkenen, 2000).

As distinct from the category sexus, the gender status, and, respectively, gender hierarchy and gender-based behavioral models are not set by nature, but they are constructed by the society (doing gender), being prescribed by the institutes of social control and cultural traditions (Morrish et al., 2007). Alongside with that, the authors of female prose prove the data of sociological investigations, that the new woman: a) Raises the increased demands to the partner, to the quality of relations, to sexual relations; b) Is in unending search for the ideal partner; c) Demonstrates "open-mindedness" with the propaganda of early sexual upbringing and youth liberation; d) shares 
sexual, matrimonial and reproductive behavior; e) Admits latent forms of sexual relations, unallowable before (homosexual relations, common-law marriage, sexual communes).

Gender relations present an important aspect of social organization. They particularly express its system characteristics and structure the relations between the speakers. The main theoretical-methodological provisions of the gender concept are based on four interrelated components: they are the cultural symbols; normative statements, specifying the directions for possible interpretations of these symbols, being expressed in religious, scientific, law and political doctrines; social institutes and organizations; self-identification of the personality (Saul, 2010; Bianchi, 2008). Gender relations are fixed in language as culturally specified stereotypes, imprinting on behavior, including speech one, personality and linguistic socialization (Cameron, 2007; Morrish et al., 2007).

In the course of investigation, the methods, traditional for gender studies, were used (Harrington et al., 2008): A method of linguistic observation and description of definite linguistic facts, in order to get the summary data, implemented by means of interpretational methodology, partial use of the component and contextual analysis; the methods of linguistic pragmatics, involving the analysis of speech modality; rhetorical analysis, presupposing the revelation of the rhetorical devices and speech figurativeness, most typical of the female discourse.

\section{Results}

Despite the fact, that the new woman in the studied texts is presented as self-sufficient, independent personality, she is in constant need to feel herself weak, to be beloved, what is connected only with the man, what is predetermined by nature (Khachmafova, 2010). A concept "MAN" in the discourse of modern Russian female prose is objectified by different means, included to its core part: man, husband, boyfriend, friend. The means of objectivation of the nearest periphery of this concept are the following synonyms: the husband, the partner, the stronger sex, the individuum, the host, the man etc.; the words with the same root: male, masculine. For instance: "He was young — aged eighteen, not more, and tall—one hundred and ninety centimeters, not less. And each millimeter was well thought out by nature. Evidently, the nature executed the strict natural selection for more than one hundred years, prior to create such individuum." (Tokareva. The Conservation Law).

The far periphery involves the following linguistic means-text associates: unscrupulous lover, champion of egoism, the object of great love, a prize in life, the builder of the best life, a luxurious animal, a fragile genius, a transit lover, guest actor etc. For instance: 1) "Finally, the door opened and a real man came in, the builder of the best life" (Tokareva. As soon as the Mist has Fallen...); 2) "She had a rarely successful love, for the sake of which she left her first indistinct husband, and she suffered from the object of her great love, gave birth to Grishka from him and was running to her scrupulous lover for the thirteenth year, had rare meetings and postponed over the years the moment of real, not one-sided acquaintance of son with the secret father" (Ulitskaya. The Queen of Spades).

The main markers, describing the man image, are the lexemes, revealing the appearance and character of the man, as viewed by women (personage and author). To depict the man image, the women-authors use the whole spectrum of figurative-vivid means of the language. The description of appearance is implemented in the following lexical units: in Russian language: "patterned man", beautiful, mysterious, disappointed as Lermontov, a beautiful beast, well-knit, beautiful, with muscles, as the Bronze Horseman, ungainly, a beautiful young man, elegant. Let us consider the examples:

1) "When he moved from place to place, it came to mind, that this man is a beautiful beast" (V. Tokareva. Horses with Wings); 2) "He was so beautiful, with muscles, as the Bronze Horseman. It was so pleasant to fall asleep and to wake up under his hard, as slab, hand" (Tokareva. To Say or not to Say).

A combination beautiful beast conveys the male beauty in women's presentation: beautiful, strong, subtle. A man with muscles presents the protection and support for a woman. The following sample reveals the woman's feature to invent the man's ideal (seemed to be), where the traits of the favorite hero are combined: "Inaccessibility makes not only woman, but also man beautiful. Trofimov seemed to be beautiful, enigmatic, disappointed, as Lermontov" (Tokareva. Do not create). A combination of external beauty and confidence in a man attracts almost all women, even if the man lacks inner brightness, for instance: "Properly, there was no any choice, and he was very attractive, well-knit and free in behavior. Although he lacked inner brightness, which was so valuable for Nika, but, frankly speaking, neither calling signals came from him" (Ulitskaya. Medea and her Children). When describing the appearance, the developing function of ontological utterances is implemented. Separate traits, details are presented as if in close-up view, the narration becomes personally-colored. For instance: "The mouth, well shaped by the chin, was the determining part of his face. As well as the smile, well grounded by his essence. The smile up to the end. The teeth were clean, pure-blooded, 
wolfish. A good smile. It was unclear with the eyes. Under the glasses. Lena could not catch their expression. Any continuous arrhythmia. The eyes of the crazy person. The good post of the neck. The span. And height. Nearly one hundred and ninety centimeters. The knees go far away under the table. It is good to hold a woman on such knees and to play with the child" (Tokareva. Anton, Put on the Shoes!).

The use of diminutive suffixes in man's description in "female" texts expresses a wide spectrum of essences: delight, love, pity, irony, affection, tenderness, contempt, disregard. For instance: “Ah, Martin, Martin! He was a reward in life, especially after two transfers. He met at the station in Zurich, in dark-green hairy coat, the same hairy hat, with short pent, raised behind, with the mottle feather sideways" (Ulitskaya. Zu-urich). The use of diminutives in female literary discourse reveals the woman's relation towards man and implement to the speech the additional emotional-expressive shades of caress, sympathy, disregard, irony etc. For instance: "He turned out to be not so young, although rather apple-cheeked, a little overweight, he was forty eight at that times! However, the face was very smooth, absolutely without wrinkles, the tan was even. Only the top of the head was bald" (Ulitskaya. Zu-urich).

The appearance, character, the sphere of heroes' activity is frequently described by means of accumulation, creating the effect of bright expression. "He was thirty seven, divorced, beautiful, no bad habits, which would catch the eyes: non-user, not the freak, the homosexual or the pedophile; presented the flowers; was not the impotent; asked about the mother's health..." (Robsky. CASUAL, The Everyday).

The man's character is described by means of the lexemes, revealing the main traits of the man's inner world, as viewed by the woman: the champion of egoism, positive man, scrupulous and independent, sly, witty, childish relaxedness, smart, reliable, tenderness towards children and independence, inaccessible. Let us illustrate the peculiarities of the man's inner world, as presented by the women-authors: "He left Lesha with the mixed feeling. This man attracted her with his dream, tenderness to children and independence”. (Krasheninnikova. Registration).

The man's character is presented in the discourse of female prose as complex, combining the opposites (talented, ungifted, egoism, creative individuality), for instance: 1) "His character, as per the dialectics law, combined the opposites: he loved his wife and other beautiful women, he was talented in communication with people and ungifted, when alone with himself, i.e. in his creative work" (Tokareva. The Conservation Law); 2) "You gives nothing. You are the champion of egoism and here is your creative individuality. You prefer to live in comfort.

-What do you mean to live in comfort?

-Comfortable job: both occupied and free. Comfortable son: he is both exists and not. Comfortable woman: you can come and leave..." (Tokareva. The Greek was Riding).

In the discourse of modern female Russian prose, the gender role of the man is revealed by means of lexical units, which reflect the number of samples of social behavior or the standards of behavior of the man in the current social position in the texts of modern women-writers: a man-husband, a man-lover, a man-child: 1) "You even do not understand, how we loved each other. Loved being sober and drunk. Especially drunk. He was a great lover" (Ulitskaya. The Women of Russian Villages); 2) "The wife impeded everywhere; she treated the husband as a schoolboy, who does not learn lessons" (Petrushevskaya. A Possibility of Mennipean. Three Voyages).

Lexical-grammatical group "Gender role" involves the lexemes, revealing the man's essence: a wedded husband, the stronger sex, a real man, a builder of the best life, a great lover, the protector, the individuum, a master of life, a small child, a son, a husband to grow into, the object of great love, unscrupulous easy-rider, scrupulous lover etc. For instance: "They had no children, but Vakhtang successfully replaced a son. He needed the food cooked, the clothes washed, he had to be consoled and he received the pocket money. However, he was not the son" (Tokareva. To Say or not to Say...).

This example demonstrates the attitude of woman towards the beloved man, as towards the son (but Vakhtang successfully replaced a son). One of the man's roles is the role of child, whom the whole mother's love is aimed at.

To characterize a man, the lexemes with positive and negative components are distinguished.

Lexico-grammatical group "Ideal" unites the lexemes, expressing positive evaluative component: divorced, beautiful, no harm habits, sober husband, staying at home and reading Dickens, a reward in life, a gift, a life, happiness, love, a heroic deed of changes, the creative flight, full independence, the dream, her dare husband, a nugget, exclusive, fragile genius, extraordinary, beautiful and impudent, he is a man to fingertips, shocking, and it is not important, drunk, sober, excellent lover, talented, tender, a wonderful person. 
The ideal man in female literary texts, is, firstly, sober and stays with family. For instance: "Her friends did not dare to dream about such happiness, as a sober husband, staying at home and reading Dickens" (Tokareva. A Long Day).

The relation of woman to contradictive advantages of the man can be illustrated by the following examples: 1) "Nevertheless, men and women are absolutely different biological individuals. Eliseev loved women. Women understood him. He could lie drunk, in snots, and they said, that he was elegant, extraordinary, fragile genius" (Tokareva. Anton, Put on the Shoes!); 2) "Butonov was an excellent lover, it was measured by centimeters, minutes, hours, the quantity of hormones in blood. He had good appearance - and that all! Your Alik is a perfect person, smart, talented. Butonov cannot hold a candle on him, but Alik is just unworthy of you.

—Shut up! — cried Masha. —Shut up! Take your Butonov with all his centimeters!” (Ulitskaya. Medea and her Children).

All above mentioned samples show, that the woman's choice of the man, as the love object, is not always understandable and not always reply to logics-He could lie drunk in snots, and they said, that he was elegant, extraordinary, fragile genius.

In ideal women's presentation, the man shall be beautiful (luxurious beast), talented (creative fly), gifted (fragile genius), excellent lover (measured in centimeters), shall be sober family man (sober husband, staying at home).

The lexico-grammatical group "Anti-ideal" in the discourse of modern female prose is presented by the lexemes with negative evaluative component: indistinct husband, complete turkey-cock, unhappy swaggerer, devil, careerist and egoist, sniveller, cissy, duster, cowardly and hesitating, cad, barnstormer, backward stub, transit lover, ungifted, ungainly. For instance: 1) "You like to strike,_said the wife.-You are the miserable swaggerer" (Tokareva. Zigzag); 2) “...I know you. You are cowardly and hesitating” (Tokareva. The Dog was walking along the Piano).

For many years of family life, such traits of man's character, as hesitation and boasting, cause sharp impatience in women. However, the fear of loneliness pushes the women to have different relationships, which do not bring the expected happiness. For instance: 1) "Lena looked at him and could not believe: was she really ready to leave this life because of this backward stub... Although, how does he come into the picture? It is just the fear of loneliness and the drive for love. It was the matter. The fear and the drive. He was just the barnstormer" (Tokareva. Anton, Put your Shoes!); 2) "Nika found the situation amusing: Mashka, a very smart girl, fell in love with such elementary sawyer. He was just for Nika: she was divorcing, her husband behaved badly, required something from her, up to flat division, her transient lover terminated the Higher Courses for Scriptwriters and Directors in Moscow and left, and permanent Kostya irritated with his serious readiness to start the married life, as soon as he got wind of the divorce" (Ulitskaya. Medea and her Children).

Sometimes the woman predetermines her fate. The desire to find the man, who would be dissolved in her, results in the fact, that the woman meets weak and weak-willed in her way, with whom she will be unhappy in a feminine way. For instance: "If she would find a man, who would be dissolved in her, he will be a sniveller, duster or sissy-she will not feel a woman near him and will be unhappy in a feminine way" (Krasheninnikova. Registration).

In the discourse of modern female prose, the man's image is revealed by means of different lexical expressive means-for instance, intensifying adjectives and adverbs, comparisons, metaphors, metonymy, periphrases, irony, the words with bright expressive coloring.

At first sight, a man in the interpretation of women-authors is presented in unattractive way: egoist, unscrupulous lover, sniveller, coward and drunkard: "She had different splendid relations: brave test-pilot and well-known Jewish academician, witty and unscrupulous lover and young actor, a tributary of early glory and earlier alcoholism" (Ulitskaya. Medea and her Children).

However, alongside with that, the heroines feel a constant need in man and tend to him throughout the whole life, connecting with him love, life, happiness, youth; he presents the reward in life. This image is brightly illustrated by the numerous samples from the texts of Russian and German female prose. For instance: "Ah, Martin, Martin! He was a reward in life, especially after two transfers. He met at the station in Zurich, in dark-green hairy coat, the same hairy hat, with short pent, raised behind, with the mottle feather sideways" (Ulitskaya. Zu-urich).

A beloved man is associated with life and happiness. When a woman connects the best is her life with him-youth, dream, a deed of changes, creative fly, small child, then he is the only man for her and the real life. For instance: 


\section{"Presentiment of happiness",-Alka would say.-Mansurov.}

Not Mansurov himself, not definite Mansurov, but everything splendid, that exists in life: youth, dream, the deed of changes, creative fly, a small child-everything named Mansurov. Do you understand?" (Ulitkaya. I Apologize. They will not shoot).

The loss of the beloved man is a great strike for a woman, compared with death, for instance: 1) "How to forget this feeling of strike, when the life, happiness and love leave you, thought Ulya, observing on a visit, how her husband sat and dried on near almost child, everybody were the adults, and she was the child" (Petrushevskaya. Where I was); 2) "She was dying, because Serezha was her life. And if there was no Serezha, there was no life" (Tokareva. One Block of Hope).

In modern female fiction, we see a persistent "search for the ideal", which reflects new tendencies in family-marriage relations of postindustrial society. Now all these changes are based on such phenomena, as the growing personal liberty, developing momentum individualism, strengthening principle "The family for a person", actualization of the human right for the intimacy, irrespective of the society. If the family arises, then the equal relations are put at the head, then the stability of marriage is determined by the quality level of mutual relations between partners.

\section{Discussion}

Thus, the representatives of female prose note the growth of psychologization and intimization in modern family, resulting in the growth of love matches and leaving the marriage of convenience. The sociologists mention (Weeks, 1996; Klesse, 2011; Georg \& Elshtain, 2006), and it is proved by modern women-writers, such situation makes the family instable due to the fact, that the partners make the psychological motives of top priority, as the demands of both men and women to the emotional sphere of marriage have increased. In modern cognitive linguistics, the text is considered as a way of fixation of individual consciousness of its author (Ewans, 2014; Leroi, 2014; Pinker, 2014). Each text is based not only on the judgment about the reality, but also on the definite communicative purposeful orientation, determined by the situation of communication and tasks, set by the author (Zamaletdinov et al., 2013; Pinker, 2011). A concept, as a key word, plays a determining role in creative process of text writing: it influences on the selection of speech figures, and also bears key ideas of personal world view, characterizes the individual style of creative linguistic personality. A concept is a unity of cognitive level in structure of female linguistic personality. A concept, verbalized in the discourse of female prose, represents the female linguistic personality and expresses the specificity of language and style of the woman-author. In the texts of female prose, a concept "MAN" is marked based on frequency marker; it is semantically loaded, as it presents one of the main concentration points of essence and energy of ideas of the woman-author. For a woman, a man stays to be a personification of her heart's desires: love, happiness and life. The search for the ideal man, the desire to the ideal life (the grief for the ideal), the feeling of loneliness and guilt accompany the woman for the whole life: grief, happiness of previous years, fear of loneliness, misfortune, to search, to wait, the last wagon of hope. In the texts of female prose, the man is "what every woman needs": "-Don't understand, don't understand,-Emma shook her head.-He is fabulous, and it is not important, if he is drunk or sober. He is the one that every woman needs. He is the man to the fingertips. He is just on hunkers. And he brought me to this terrible situation. He is not guilty. Just the circumstances..." (Ulitskaya. The Women in Russian Villages). The fear of loneliness and the drive for love exist in the life of each woman. For instance: "Although, how does he come into the picture? It is just the fear of loneliness and the drive for love. It was the matter. The fear and the drive" (Tokareva. Anton, Put on the Shoes!). The text of female prose is a dynamic verbal object, generated by the individual consciousness of the woman-author and fixing the specificity of the female linguistic world view. It is characterized a functionally determined sequence of speech actions, each of which implements the relation of the woman-author to the item values of the literary text.

Alongside with that, it shall be confessed that there is a dichotomy, reflecting "old" orientations on woman's behavior in family, love, society (Al-Batini \& Wells, 1987) and "new" realties, where the woman is the same equal and equipollent partner, as a man (Khachmafova, 2007; Ferrary, 2010). Thus, the female literary text is a vivid and adequate mean to translate the conceptual worldview of the woman, who has an individual character, fixes and analyzes the notional, emotional, associative culturological content of worldview objects.

\section{Conclusion}

The linguistic consciousness of the woman, the author of the literary text, is unmatched and unique, that is reflected on the level of text-discursive-model of its presentation. The woman herself finds the reason of her sufferings, inner feelings. She has another status in the society, than the man. "She has the experience, inaccessible to the man: pregnancy. The woman is put by nature on the edge of entwinement and periodical 
alternation of birth and death, and this inner connection through the organism with the natural, elemental, determines the woman's consciousness in whole" (Dark, 1991). From this follows that the natural predetermination of the woman "cuts from culture and culture creation" (Ryutkenen, 2000). For instance: "It is not for nothing, that in the Biblical legend, the woman chose the fruit of knowledge-Who pays, that one chooses. Who chooses, the one cries. She is the one, who gives birth, and pays for upright posture and great brain. For being equal to Gods-pain in labor" (Sukhanova). A concept "MAN", being one of the basic categories in the investigation of individual-author linguistic worldview of the female prose, expresses the author's interpretation of common cultural concepts. Lexical means of the "MAN" concept explication, revealed in the course of analysis of lexical organization of text fragments, representing this implementation of the dominant topic, can be presented in the view of several text lexical unifications-lexico-semantic groups: "Image", "Gender role", "Ideal", "Anti-ideal".

The investigation provides us with the presentation about the woman-writer's world outlook- the result of interaction of woman's personality value system, worldview with her life values, goals, behavioral motives, orientations, shown, in particular, in the produced texts. Alongside with that, the female prose vividly demonstrates the evolution of stereotypes in Russian society relatively sexual, matrimonial and reproductive behavior of the woman. Accentuation on basic concepts of modern woman's inner world speaks about those changes that took place in the woman's life: from full subordination to the man to the appearance of proper imaginative nature in the society.

The pieces of female fiction are studied "as a field of gender stereotypes functioning (the concepts of masculinity and femininity, accepted in the society), gender roles (samples of behavior, expected from men and women) (Baxter \& Al-A'ali, 2014; Cameron, 2012). Thus, the following factors become the motivation for marriage: 1) Psychological separation from the paternal home; 2) Love; 3) Legalization of existing sexual relations; 4) Legal registration of antenuptial pregnancy; 5) Marital status to get different social preferences (dwelling, in the first place); 6) Actualization of reproductive behavior (the desire to have children); 7) The possibility to move and to live in the city; 8) Conformism (to be equal to everybody); 9) Idealization of modern partnership in the marriage. In gender study of literature, we took into consideration a number of factors: problematic-thematic specificity; the system of personages (behavioral models, inner world, psychology, typology); speech (discourses of man-heroes and women-heroines); narrative-compositional organization; conflict; subject organization (first of all, the plans of viewpoints and narrative instances (the author, the narrator, the hero); chronotopous; stylistics; the author's worldview, the character of consciousness. The analysis shows that women's sexual, reproductive and matrimonial behavior is all rolled into one, presenting a complex poly-aspect and mega-conceptual phenomenon of the gender-conditioned personality, which began to assert itself in fiction of contemporaneity.

\section{References}

Al-Batini, \& Suzi, W. (1987). Traditions: The folklore of women and children in Kuwait (p. 152). Kuwait bookshops LTD.

Avery, J. D., \& Liss, J. M. (1996). Acoustic characteristics of less-masculine-sounding male speech. Journal of the Acoustical Society of America, 99(6), 3738-3748. http://dx.doi.org/10.1121/1.414970

Baxter, J., \& Al-A'ali, H. (2014). Your situation is critical: The discursive enactment of leadership by business woman in Middle Eastern and Western European contexts. Gender and Language, 8(1), 91-116. http://dx.doi.org/10.1558/genl.v8i1.91

Bianchi, C. (2008). Indexicals, speech acts and pornography. Analysis, 68(4), 310-316. http://dx.doi.org/10.1093/analys/68.4.310

Cameron, D. (2007). The myth of Mars and Venus: Do men and women really speak different languages? (pp. 208). Oxford University Press.

Cameron, D. (2012). On language and sexual politics (p. 208). Routlrdge.

Castro, O. (2013). Talking at cross-purposes? The missing link between feminist linguistics and translation studies. Gender and Language, 7(1), 35-58. http://dx.doi.org/10.1558/genl.v7i1.35

Clarck, J. (2012). Language, sex and social structure: Analyzing discourses of sexuality (p. 176). Palgrave Macmillan. http://dx.doi.org/10.1057/9781137283986

Dark, O. (1991). Female antinomies. The Friendship of Nations, 4, 253-257.

Derrida, J. (2012). The fields of philosophy (p. 376). M.: Academic Project.

Ewans, V. (2014). The language myth: why language is not an instinct? (p. 314). Cambridge University Press. 
http://dx.doi.org/10.1017/CBO9781107358300

Ferrary, F. (2010). Gender and identification in political discourse: the American woman as a category of analysis. The Herald of Adygei State University, 1, 39-54.

Georg, R. P., \& Elshtain, J. B. (2006). The meaning of marriage: Family, state, market and moralis (p. 336). Spence Publiching Company.

Gvozdeva, A. A., Riabtseva, E. V., \& Tsilenko, L. P. (2005). Third wave feminist linguistics. Herald of Tambov State Technological University, 11(1), 300-309.

Harrington, K., Litosseliti, L., Sauntson, H., \& Sunderland, J. (2008). Gender and language research methodologies (p. 352). Palgrave Macmillan.

Hart, C. (2010). Critical discourse analysis and cognitive science (p. 256). Hertfordshire: Palgrave Macmillan. http://dx.doi.org/10.1057/9780230299009

Karabulatova, I. S. (2004). The culture of childhood of Tyumen region: traditions and contemporaneity (p. 268).

Karabulatova, I. S. (2013). The problems of linguistic modeling of new Eurasian linguistic personality in multilinguistic and mental environment (by example of onomasphere). Middle-East Journal of Scientific Research, 17(6), 791-795.

Khachmafova, Z. R. (2007). The main parameters and characteristics of linguo-cultural personality. Actual Problems of Linguistic Education: The Materials of International Scientific-Practical Conference.

Khachmafova, Z. R. (2008). Actual directions in the study of female linguistic personality in modern linguistics. The Herald of Moscow State Regional University, Russian Philology, 2, 28-22. Moscow: MSRU.

Khachmafova, Z. R. (2009). Conceptual orientation of female prose. The Herald of Adygei State University, 2, 219-224. Maikop: ASU.

Khachmafova, Z. R. (2010). Female linguistic personality in the literary text: Cognitive-functional and linguo-culturological aspects (based on Russian and German languages, p. 282). Maikop: ASU.

Klesse, C. (2011). Notions of love in polyamory-elements in a discourse on multiple loving. A Magazine of Social Investigations, 2, 4-25.

Lazar, M. M. (2007). Feminist critical discourse analysis. Gender, power and ideology in discourse (p. 272). Palgrave Macmillan. http://dx.doi.org/10.1057/9780230599901

Leroi, A. M. (2014). The Lagoon: How Aristotle invented science (Tra Edition, p. 512). Viking Adult.

Lotman, Y. M. (1994). Lectures on structural poetics. In Yu. M. Lotman and Tartuss-Moscow Semiotic School (pp. 10-257). M.: Gnosis.

Morrish, L., Morrish, E., \& Sauntson, H. (2007). New perspectives on language and sexual identity (p. 223). Pagrave Macmillan. http://dx.doi.org/10.1057/9780230599406

Okhotnikova, S. (2002). The first part. Gender investigations in literary studies: The problems of gender poetics. (p. 113). Ivanovo.

Petrushevskaya, L. (2000). The possibility of Mennipea. Three Voyages. Retrieved December 4, 2014, from http://books.imhonet.ru/element/10811/

Petrushevskaya, L. (2002). Where I was (p. 302). M.: Vagrius.

Pinker, S. (2014). Sense of style: the thinking person's guide to writing in the 21st century (p. 358). Viking Adult.

Pinker, S. (2011). Words and rules. The ingredients of language (Reprint edition, p. 358). Harper Perennial.

Pischler, P. (2009). Talking young feminities (p. 256). Palgrave Macmillan. http://dx.doi.org/10.1057/9780230234598

Posch, C. (2009). Feminist linguistics and corpus linguistics: A database of gender fair language use with non-human referents (PhD Thesis). University of Innsbruck.

Queen, R. (1997). I don't speak Spritch: Locating lesbian language. Queerly Phrased: Language Gender and Sexuality (pp. 233-242). London: Routledge.

Robsky, O. (2005). CASUAL/The everyday (p. 336). M.: Rosmen-Press.

Ryazantsev, S. V., Pismennaya, E. E., Karabulatova, I. S., \& Akramov, S. Y. Transformation of sexual and matrimonial behavior of Tajik labour migrants in Russia. Asian Social Science, 10(20), 1911-2025. 
http://dx.doi.org/10.5539/ass.v10n20p1

Ryutkenen, M. (2000). Gender and literature: The problem of "women's writing" and "women's reading". Philological sciences, M., 3. Retrieved May 10, 2014, from http://www.a-z.ru/women_cd1/html/filologich_nauki_2.htm

Saul, J. (2010). Feminist philosophy of language. Stanford encyclopedia of Philosophy. Retrieved December 11, 2014, from http://plato.stanford.edu/entries/feminism-language/

Sunderland, J. (2011). Language, gender and children's fiction (p. 259). A\&C Black.

Tokareva, V. (1991). To say or not to say. M.: Slovo. Retrieved November 29, 2014, from http://www.libok.net/writer/2044/kniga/55617/tokareva_viktoriya_samoylovna/skazat_-_ne_skazat

Tokareva, V. (1995). Instead of me. M.: EKSMO. Retrieved December 11, 2014, from http://www.libok.net/writer/2044/kniga/49460/tokareva_viktoriya_samoylovna/vmesto_menya/read

Tokareva, V. (1995). The dog was walking along the piano (p. 522). M.: Lokid.

Tokareva, V. (2000). A long day. M.: AST. Retrieved December 1, 2014, from http://books.imhonet.ru/element/13864/

Tokareva, V. (2001). Anton, put on the shoes. M.: AST. Retrieved November 27, 2014, from $\mathrm{http}$ ://bookz.ru/authors/tokareva-viktoria/anton-n_084.html

Tokareva, V. (2004). The horses with wings. M.: AST. Retrieved November 30, 2014, from http://www.libok.net/writer/2044/kniga/55579/tokareva_viktoriya_samoylovna/loshadi_s_kryilyami/read

Tokareva, V. (2007). Apologize. I will not be shoot. M.: AST. Retrieved December 5, 2014, from http://romanbook.ru/book/1176454/

Tokareva, V. (2007). The conservation law. M.: AST. Retrieved December 9, 2014, from http://iknigi.net/avtor-viktoriya-tokareva/34973-zakon-sohraneniya-viktoriya-tokareva.html

Tokareva, V. (2007). The Greek was riding. M.: AST. Retrieved November 27, 2014, from http://mybook.ru/author/viktoriya-tokareva/ehal-greka/

Tokareva, V. (2008). Zigzag. M.: AST. Retrieved December 2, 2014, from http://bookz.ru/authors/tokareva-viktoria/zigzag_647.html

Tokareva, V. (2011). As soon as the mist has fallen. (p. 9). M.: LitRes. Retrieved December 4, 2014, from http://bookz.ru/authors/tokareva-viktoria/uj-kak-p_376/1-uj-kak-p_376.html

Tokareva, V. (2011). Do not create. Retrieved November 28, 2014, from http://www.libok.net/writer/2044/kniga/55588/tokareva_viktoriya_samoylovna/ne_sotvori

Tokareva, V. (2011). One block of hope. M.: AST. Retrieved December 1, 2014, from http://www.litmir.net/bd/?b=71281

Ulitskaya, L. (2001). The queen of spades. M.: Vagrius. Retrieved October 15, 2014, from http://www.libok.net/writer/12584/kniga/55659/ulitskaya_lyudmila_evgenevna/pikovaya_dama_i_drugie/re ad

Ulitskaya, L. (2005). Zu-urich (pp. 196-265). M.: EKSMO. Retrieved November 18, 2014, from http://www.libok.net/writer/12584/kniga/53832/ulitskaya_lyudmila_evgenevna/tsyu-yurih

Ulitskaya, L. (2008). The women of Russian villages. M.: AST. Retrieved October 16, 2014 from http://www.litres.ru/ludmila-ulickaya/zhenschiny-russkih-seleniy/

Ulitskaya, L. (2012). Medea and her children. Retrieved October 19, 2014, from http://mexalib.com/view/93733

Weeks, J. (1996). Sexual cultures: community, values and intimacy (p. 228). Palgrave Macmillan.

Zamaletdinov, R. R., Karabulatova, I. S., Saifulina, F. S., \& Vasilishina, E. N. (2013). Linguo-culturological aspect in implementation of discursive implications in blend space "a hero- a doll—a hand puppet" (based on "synthetic" prose of Nabokov, V. V.). The Herald of Orel State University, 5(34), 134-139.

Zherebkina, I. (2000). Read my wish.... Postmodernism. Psychological Analysis. Feminism (p. 256). M.: Idea-Press.

Zherebkina, I. A. (2002). Introduction to gender studies (p. 712). St. Petersburg: Aleteya, HTSGI. 


\section{Copyrights}

Copyright for this article is retained by the author(s), with first publication rights granted to the journal.

This is an open-access article distributed under the terms and conditions of the Creative Commons Attribution license (http://creativecommons.org/licenses/by/3.0/). 